\title{
A comparison of different solarisation systems and their impacts on soil thermal characteristics-an application in cultivated soils close to Baghdad, a highly populated city in Iraq
}

Ahmed Abed Gatea Al-Shammary, 1,2 $\square$

Emailagatea@deakin.edu.au 
Abbas Kouzani, 1

Yeboah Gyasi-Agyei, 3

Jesús Rodrigo-Comino, 4,5

1 School of Engineering, Deakin University, Geelong, VIC, 3216 Australia

2 Soil Science and Water Resources Departments, College of

Agriculture, University of Wasit, Kut, Iraq AQ1

3 School of Engineering and Technology, Central Queensland

University, Rockhampton, QLD, 4702 Australia

4 Department of Physical Geography, University of

Trier, 54296 Trier, Germany

5 Soil Erosion and Degradation Research Group, Department of

Geography, University of Valencia, Avda. Blasco Ibáñez, 28, 46010 Valencia, Spain

Received: 14 August 2019 / Accepted: 22 November 2019

\section{Abstract}

Solarisation application by mulching the soil with a polyethene plastic film has a significant influence on soil thermal characteristics (TCs), which, in turn, show a strong impact on soil energy balance and agricultural productivity. In countries like Iraq with highly populated cities, such as Baghdad, that need large quantities of agriproducts, this kind of clean energy should play a key role in sustainable agricultural production. However, little is known about the effects of different soil solarisation systems in specific cultivated fields for this country characterised by an arid climate and silty clay soils. Therefore, an experimental study was conducted to investigate changes in soil TCs under different soil solarisation systems (black and clear plastics) at three different soil depths in a two-factor factorial design. Also, both the black and clear plastic plots were compared with a control (without mulch) plot treatment. 
Three different soil TCs were assessed, namely soil thermal flux ( \# 7 it is $q h$ please format $h$ ), soil thermal conductivity $(k)$, and soil volumetric heat capacity $\left(C_{\mathrm{v}}\right)$. The results of this study indicated that the soil solarisation application had a significant influence on soil TCs. Soil 㐏 it is qh please format $h$ decreased with increasing soil depth, while $k$ and $C_{\mathrm{v}}$ exhibited an opposite trend. The black plastic mulch treatment produced higher soil 㐏 it is $q h$ please format $h, k$, and $C_{\mathrm{v}}$ values than both the clear plastic and the control treatments. Moreover, high diurnal variability of the TCs was also registered, and the clear plastic conserved a higher temperature than the black one during the night hours. During daylight, the black mulch reached a maximum temperature of $70{ }^{\circ} \mathrm{C}$. It is recommended that more research should be conducted to get new insights on the interplay of the different seasons, and different crops and soil types.

\section{Keywords}

Soil energy balance

Solarisation

Plastic mulch

Soil thermal characteristics

Agricultural management system

Urban areas

\section{Introduction}

A drastic increase in population and globalisation has called for the redesign of agricultural management systems to increase food production without harmful effects on soil quality (Milligan and O'Keeffe 2018; Brevik et al. 2019). Due to these demographic and economic changes, renewable energies and their combination with sustainable agricultural management systems should play a vital role for designing efficient land management plans, and achieving land degradation neutrality (Keesstra et al. 2018; Griggs et al. 2013).

The combination of renewable energies and sustainable agricultural management systems should be mandatory for urban areas which experience the highest demand for food and energy (Godfray et al. 2010). One example of renewable energy is thermal energy, which should be considered a high priority in 
underdeveloped arid and semi-arid countries characterised by highly populated cities (da Silva et al. 2018; Steinmetz et al. 2016). However, in an extensive review conducted by Kasirajan and Ngouajio (2012), the applications and studies of sustainable plastic mulches and their impacts on soil thermal characteristic (TCs) are devoid of environmental and agronomic perspectives.

Thermal energy, being able to modify soil properties, has been studied as an important parameter of soil systems (Wilhelm and Bockheim 2016; Mengistu et al. 2017). TCs show a key influence on soil energy balance and soil temperature (Pramanik et al. 2015). It is well-known that thermal energy can be transferred by convection and conduction. However, soil TCs in cultivated fields are dynamic because they are primarily dependent on the effects of certain mechanical human alterations such as tillage, and inherent natural conditions such as soil bulk density and moisture content (Hu et al. 2016; Wilhelm and Bockheim 2016; Alrtimi et al. 2016).

Knowing the positive and negative effects of solarisation techniques on soil properties, and when and where these practices have started, is very useful. The implementation of solarisation technology has been assessed by many investigations under different soil management systems and environmental conditions in more than 60 countries (Gamliel and Katan 2005), particularly in arid and semi-arid climates (e.g. J Katan et al. 1976; Pullman et al. 1979; Shi et al. 2018; Al-Shammary and Al-Sadoon 2014a). Solarisation increases crop productivity by modifying some key soil properties such as increasing the soil porosity and conserving soil moisture content as a result of the reduction in evaporation (Zribi et al. 2015). Some authors have also highlighted that soil aggregation can be improved (Kader et al. 2017) and soil salinity can be reduced (M. Zhang et al. 2018) by solarisation application. However, recent research has confirmed that solarisation may show some negative impacts on soil quality. The drastic variation of soil temperature and moisture content could destroy some beneficial soil microbial communities, such as Bacilli and Gammaproteobacteria, Actinobacteria, Alphaproteobacteria, and Acidobacteria (Kanaan et al. 2018). AQ2

Soil tillage plays an important and recognised role in soil management practices in agricultural fields by modifying soil physical properties (Al-Kaisi et al. 2005; Bogunovic et al. 2017b), or by enhancing soil and water mobilisation (Alliaume 
et al. 2014; Martínez-Casasnovas and Sánchez-Bosch 2000). However, its impact is different at distinct soil depths that need to be assessed. Accordingly, tillage depth also affects solarisation effectivity because of gains and losses of soil heat transfer energy throughout the soil profile as a result of changes in colour, compaction, moisture, organic matter, and porosity, among others.

There has been an increasing amount of literature on soil TCs under different environmental conditions. Recently, the main TCs considered are the thermal flux ( 㐏 it is $q h$ please format $h$ ), soil thermal conductivity $(k)$, and soil volumetric heat capacity $\left(C_{\mathrm{v}}\right)$ (Łydżba et al. 2016; Li et al. 2016; Alrtimi et al. 2016; Levy and Schmidt 2016). These TCs are strongly dependent on soil mineral composition, bulk density $\left(\rho_{\mathrm{b}}\right)$, moisture content $(\mu)$, and soil texture (Łydżba et al. 2016). However, the effectiveness of a soil solarisation system, and its impact on TCs, also varies with the type of mulch used. For example, Li et al. (2016) studied the impact of plastic mulch on soil flux density. They found that plastic mulch reduced soil evaporation, which influences soil TCs, and had a significant influence on soil 蔳 it is $q h$ please format $h$. A recent study conducted by Levy and Schmidt (2016) in Antarctic soils demonstrated that soil $k$ and $C_{\mathrm{v}}$ are dependent on $\mu$, and both increase with soil depth. Furthermore, studying the effects of soil $\rho_{\mathrm{b}}, \mu$, and organic matter on soil thermal conductivity, they discovered that $k$ increases with soil $\rho_{\mathrm{b}}$ and $\mu$. Alrtimi et al. (2016) investigated the differential impacts of soil porosity $(\Phi)$ and volumetric moisture content $(\theta)$ on soil $k$. They found a relationship between soil $k, \Phi$, and $\theta$, and that soil $\rho_{\mathrm{b}}$ increases soil $k$. Dong et al. (2016) evaluated soil $\mu$ and thermo-hydraulic properties by estimating soil temperature at different depths. They demonstrated that soil's hydraulic properties significantly influenced soil $\mu$ because of their impact on soil heat transfer. Furthermore, they established that soil TCs can be estimated from soil hydraulic properties and soil condition.

In arid and semi-arid areas close to big populated urban areas with an elevated number of sunny hours, the variations of TCs along the soil profile is not wellknown. However, this knowledge will allow farmers to decide on a more sustainable and effective mulch type. Therefore, an experimental study was conducted to investigate changes in soil TCs under two different soil solarisation systems (black and clear plastics) at three different soil depths in a two-factor factorial design. Both solarisation systems plots were compared with a control 
plot without any mulch. Three different soil TCs were assessed, namely soil thermal flux $(q h)$, soil thermal conductivity $(k)$, and soil volumetric heat capacity $\left(C_{\mathrm{v}}\right)$. A field experiment was conducted on experimental plots in the highly populated city of Baghdad, Iraq, with a representative soil type cultivated with the wheat crop.

\section{Materials and methods}

\section{Study area}

The experimental field ( $\left.33^{\circ} 13^{\prime} 59.8^{\prime \prime} \mathrm{N}, 44^{\circ} 27^{\prime} 52.6^{\prime \prime} \mathrm{E}\right)$ is located in the AlRabyaa station which belongs to the Agriculture Ministry in Zafaraniah/Baghdad, Iraq, and is in a slightly undulating area. The experimental procedure was carried out during summer (from June 1, 2015 to September 1, 2015 ) in order to get the maximum solar energy, and also to avoid problems of excessive rainfall since summer months are generally dry. The experimental plot is characterised by the subtropical aridity of the Arabian Desert and the subtropical humidity of the Arabian Gulf, experiencing a mean annual rainfall of $160 \mathrm{~mm}$ (Alzubaydi and Alamar 2016; Al-Shammary et al. 2016). The climate is characterised by a long, hot, and dry summer with an average relative humidity of $26.9 \%$, and an average temperature of $34.6{ }^{\circ} \mathrm{C}$. The parent material belongs to the lithological group of sedimentary rocks with an average depth of groundwater higher than $150 \mathrm{~cm}$ (Almahmood 2010).

\section{AQ3}

Prior to establishing the crops, seeds of Alhagim aurorum (a legume species), Cynodon dactylon (a grass species), and Imperata cylindrical (a grass species) were spread to serve as cover crops. According to the US Department of Agriculture Soil Survey Staff (1975) classification system, the soils are silty clay because of the high contents of clays $(>40 \%)$ and silts $(>40 \%)$ (Table 1$)$. The soils are cultivated with wheat and barley which are under surface irrigation with water sourced from the Tigris River.

\section{Table 1}

The average physical and chemical properties of the studied soils

\begin{tabular}{|c|c|c|c|c|c|c|c|c|c|c|}
\hline Soil & & 101 & SOM & & SD ( & & & & & \\
\hline$(\mathbf{c m})$ & $\left(\mathrm{g} / \mathrm{cm}^{2}\right.$ & $(\%)$ & $(\%)$ & Clay & Silt & Sand & (ds & $\mathrm{CO}_{3}^{-2}$ & $\mathrm{HCO}_{3}{ }^{-1}$ & \\
\hline
\end{tabular}




\begin{tabular}{|c|c|c|c|c|c|c|c|c|c|c|}
\hline \multirow{2}{*}{$\begin{array}{c}\text { Soil } \\
\text { depth } \\
\text { (cm) }\end{array}$} & \multirow{2}{*}{$\begin{array}{c}\text { BD } \\
\left(\mathrm{g} / \mathrm{cm}^{3}\right)\end{array}$} & \multirow{2}{*}{$\begin{array}{l}\text { SM } \\
(\%)\end{array}$} & \multirow{2}{*}{$\begin{array}{c}\text { SOM } \\
(\%)\end{array}$} & \multicolumn{3}{|c|}{ PSD (\%) } & \multirow{2}{*}{$\begin{array}{c}\mathrm{EC} \\
\left(\mathrm{ds} / \mathrm{m}^{-1}\right)\end{array}$} & \multirow[b]{2}{*}{$\mathrm{CO}_{3}^{-2}$} & \multirow[b]{2}{*}{$\mathrm{HCO}_{3}{ }^{-1}$} & \multirow[b]{2}{*}{$\mathrm{CI}^{-}$} \\
\hline & & & & Clay & Silt & Sand & & & & \\
\hline $0-10$ & 1.21 & 31 & 8.0 & 47 & 41 & 12 & 2.06 & 0 & 7 & 13 \\
\hline $10-20$ & 1.24 & 32.6 & 4.8 & 45 & 41 & 14 & 1.70 & 0 & 9 & 8 \\
\hline $20-30$ & 1.29 & 38 & 4.0 & 41 & 43 & 16 & 1.34 & 0 & 10 & 3 \\
\hline
\end{tabular}

$B D$, bulk density; $S M$, soil moisture; $S O M$, soil organic matter; $P S D$, particle size distribı

\section{Experimental design and data analysis}

Field experiments were conducted to investigate the impact of soil solarisation technology, using two different types of plastic mulch, examining three soil characteristics of thermal flux ( $\overline{7}$ it is $q h$ please format

$h)$, thermal conductivity $(k)$, and volumetric heat capacity $\left(C_{\mathrm{v}}\right)$ at different soil depths. For the experimental design and management of treatments, the variables were selected in a two-factor factorial design. The first factor was the soil tillage depth at three different levels of 10,20, and $30 \mathrm{~cm}$. The second factor was the mulching type being clear plastic mulch (CM), black plastic mulch (BM), and the control without mulch (WM) (Fig. 1). In the current study, the soil field was ploughed by a disc plough (DP) followed by a spring disk using a tractor (Same Explorer 85 DT). Three replications were considered, each replica consisting of nine ( 3 types of soil management $\times 3$ soil depths) experimental plots of $2 \times 2 \mathrm{~m}$ (Fig. 1). The experimental field was irrigated to $100 \%$ field capacity by surface irrigation, and the mulched experimental field plots were covered with a $0.5-\mathrm{mm}$ thick polyethene film after $48 \mathrm{~h}$. The field was monitored from June 25, 2015 to August 7, 2015. The polyethene film was carefully unrolled and perfectly attached to the soil surface to increase the solarisation efficiency (Jaacov Katan and DeVay 1991). Plastic straps were also installed in at least two places to prevent blowing of dust underneath.

\section{Fig. 1}

Schematic diagram of the experimental field layout. Ti represents soil treatments of replication i; shaded circles with crosses represent the thermocouple location at $10 \mathrm{~cm}$ (blue), $20 \mathrm{~cm}$ (orange), and $30 \mathrm{~cm}$ (green) depths 


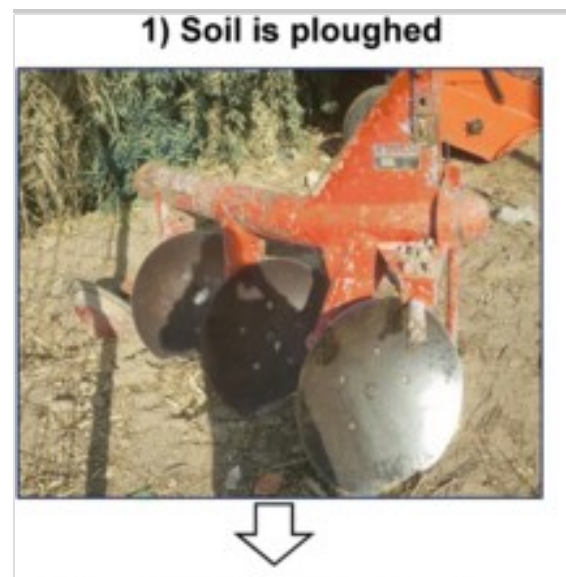

2) Installation of black and clear plastics, and control plot
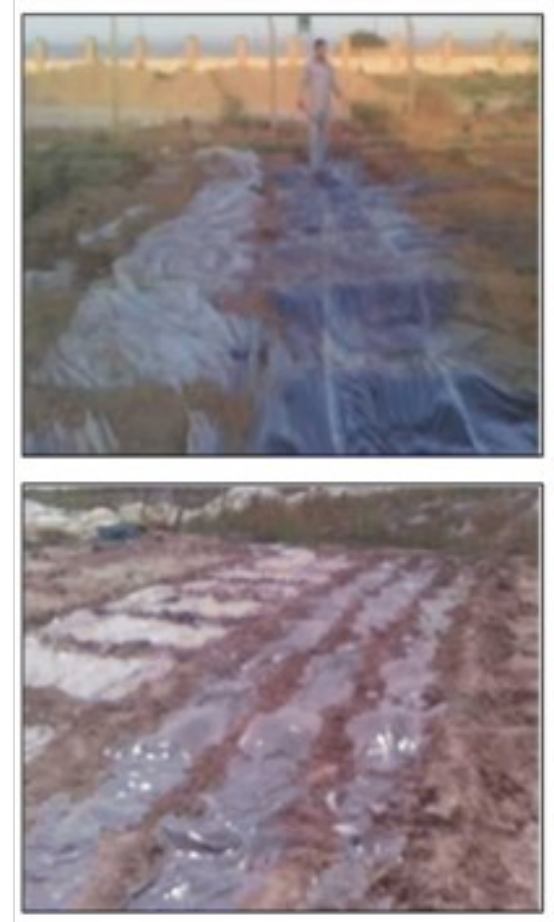

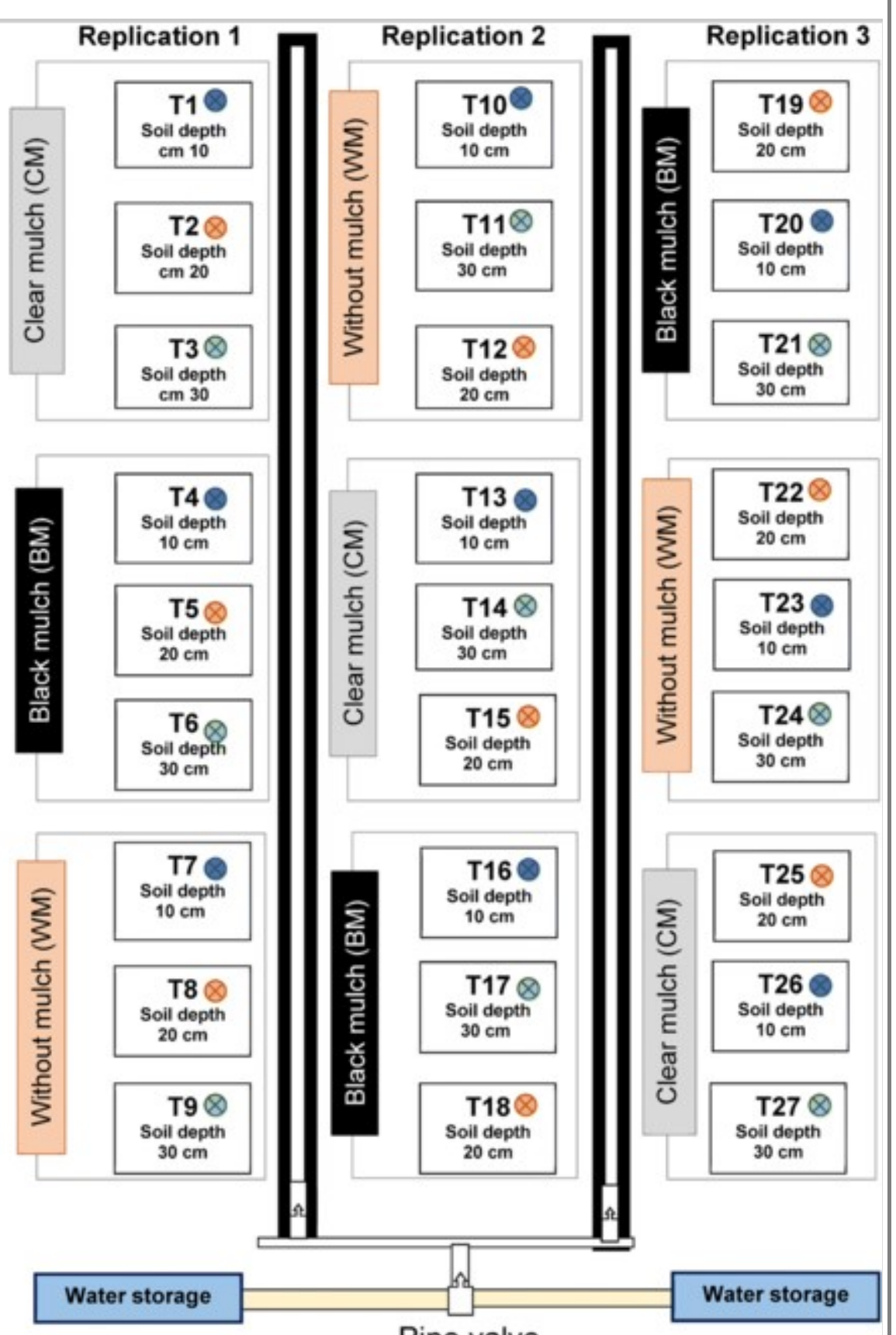

Pipe valve

In the next step, a thermocouple-type (K) thermometer (MT-4011) was installed at each of the three soil depths, as well as between the mulch and soil surface, for hourly measurements of soil temperature from 9:00 to 15:00 h (24-h clock format). Finally, on August 7, 2015, calculations of the soil bulk density $\left(\mathrm{g} \mathrm{cm}^{-3}\right)$, porosity $(\%)$, volumetric moisture content $\left(\mathrm{cm}^{3} \mathrm{~cm}^{-3}\right)$, thermal conductivity $\left(\mathrm{W} \mathrm{m}^{-1} \mathrm{~K}^{-1}\right)$, volumetric heat capacity $\left(\mathrm{J} \mathrm{m}^{-3} \mathrm{~K}^{-1}\right.$ ), and thermal flux $\left(\mathrm{W} \mathrm{m}^{-2}\right)$ were carried out after removing the covers from the treatment units. 
Soil heat flux density, 烎 it is $q h$ please format

$h\left(\mathrm{~W} / \mathrm{m}^{2}\right)$, is a single-valued function of soil thermal conductivity, $k(\mathrm{~W} / \mathrm{m} \mathrm{K})$ and was calculated as (Evett et al. 2012):

$$
q h=-k \frac{d t}{d x}
$$

where $d t$ is the difference in soil temperature $(\mathrm{K})$ between two depths, and $d x$ is the vertical distance between the depths $(\mathrm{m})$.

Soil thermal conductivity $(k)$ was estimated using Eq. 2 (N. Zhang and Wang 2017):

$$
k=0.1442[0.9 \log \mu-0.2] 10^{0.01 p b}
$$

where $\mu$ is soil moisture content by weight (\%) and $\rho_{\mathrm{b}}$ is soil bulk density $\left(\mathrm{g} / \mathrm{cm}^{3}\right)$. Then, the soil bulk density was calculated as (Smith 2000$)$ :

$$
\rho b=\frac{M_{\mathrm{s}}}{V_{\mathrm{t}}}
$$

where $M_{\mathrm{s}}$ is the oven-dried soil weight $(\mathrm{g})$ and $V_{\mathrm{t}}$ is the soil volume $\left(\mathrm{cm}^{3}\right)$.

Finally, the volumetric heat capacity, $C_{\mathrm{v}}\left(\mathrm{J} / \mathrm{m}^{3} \mathrm{k}\right)$, was calculated considering Eq. 4 (Evett et al. 2012):

$$
C_{\mathrm{v}}=\frac{2.01 \times 10^{6} p b}{2.65+4.19 \times 10^{6} \theta}
$$

where $\theta$ is the volumetric moisture content $\left(\mathrm{cm}^{3} / \mathrm{cm}^{3}\right)$, which was calculated as (Smith 2000):

$$
\theta=\frac{p_{\mathrm{w}} \times p_{\mathrm{b}}}{d_{\mathrm{w}}}
$$

where $p_{\mathrm{w}}$ is moisture content by weight $(\%)$ and $d_{\mathrm{w}}$ is water density $\left(\mathrm{g} / \mathrm{m}^{3}\right)$.

The main descriptive statistics of the average, standard deviation, maximum, and minimum were calculated and presented in tables and depicted in box plots. The 
interaction effects of the experimental factors among treatments were obtained using a two-factor ANOVA. The main goal was to confirm whether the variables (factors) are significant, either separately (namely main effects) or in combination (via an interaction), and which is the included effect of the two analysed factors on soil thermal characteristics. Equal variance and Shapiro-Wilk tests were also carried out to confirm if the results follow a normal distribution. However, all the data showed no normal distribution. Therefore, the Tukey test was applied in order to assess differences among the plots. When significant differences were found, a post hoc test was used. Finally, the least significant design (LSD) analyses at 0.05 confidence level were performed to compare the means of the treatments. All statistical analyses were carried out using the SAS 9.4 software and SigmaPlot v.13 (Systat Software Inc.).

\section{Soil sampling and analysis}

The soil sampling procedure involved several steps. Firstly, the experimental site was cleared of plant waste, and then, soil samples were collected from the field at three depths $(0-10,10-20$, and 20-30 cm). Samples were then smoothed by passing them through a 2-mm-diameter sieve and dried at ambient air conditions. Soil mechanical analysis was performed using a triangular diagram according to the United States Department of Agriculture (USDA) texture classification. Electric conductivity (EC) was measured according to the procedure of (Krishna 2016). Soil pH was analysed following (Vogt et al. 2015), and for the organic matter by the method of (Kroetsch and Wang 2007). Soil $\rho_{\mathrm{b}}$ was measured by the core method as detailed by (Walter et al. 2016).

\section{Results}

\section{Soil properties}

Table 1 presents the average of the soil's physical and chemical properties at the 3 depths. The soil layer 20-30 cm depth recorded the highest values of bulk density, averaging $1.29 \mathrm{~g} \mathrm{~cm}^{-3}$. The lowest values were recorded at the surface $(0-10 \mathrm{~cm})$ with an average of $1.21 \mathrm{~g} \mathrm{~cm}^{-3}$, indicating that this soil property increases with depth. Similarly, the deepest layer $(20-30 \mathrm{~cm})$ registered the highest average soil moisture of $38 \%$, while the lowest (31\%) was recorded at the surface. The highest average soil organic matter ( $8 \%$ ) was found at the $0-10 \mathrm{~cm}$ depth, and the other soil layers showed less than $5 \%$ organic matter content. 
Moreover, the average electrical conductivity indicated higher values at the surface (up to $20.06 \mathrm{ds} / \mathrm{m}^{-1}$ ) compared with the deeper layers. Finally, it is important to highlight that all the soil nutrients showed higher values at the surface layers $(0-10 \mathrm{~cm})$ than in the deeper ones $(10-20$ and $20-30 \mathrm{~cm})$. Only $\mathrm{Mg}^{+2}$ registered the highest value at the middle layer of $10-20 \mathrm{~cm}$.

\section{Soil temperature changes}

Figure 2 depicts the average diurnal soil temperature variation for the black, clear, and control treatments at each of the 3 soil layers. The Tukey test was applied to check whether there are statistically significant differences in diurnal soil temperature changes for the soil depths and treatments (Table 2).

\section{Fig. 2}

Diurnal average soil temperature $\left({ }^{\circ} \mathrm{C}\right)$ variations for the gap between mulch and soil surface and at the three soil depths for each soil management system
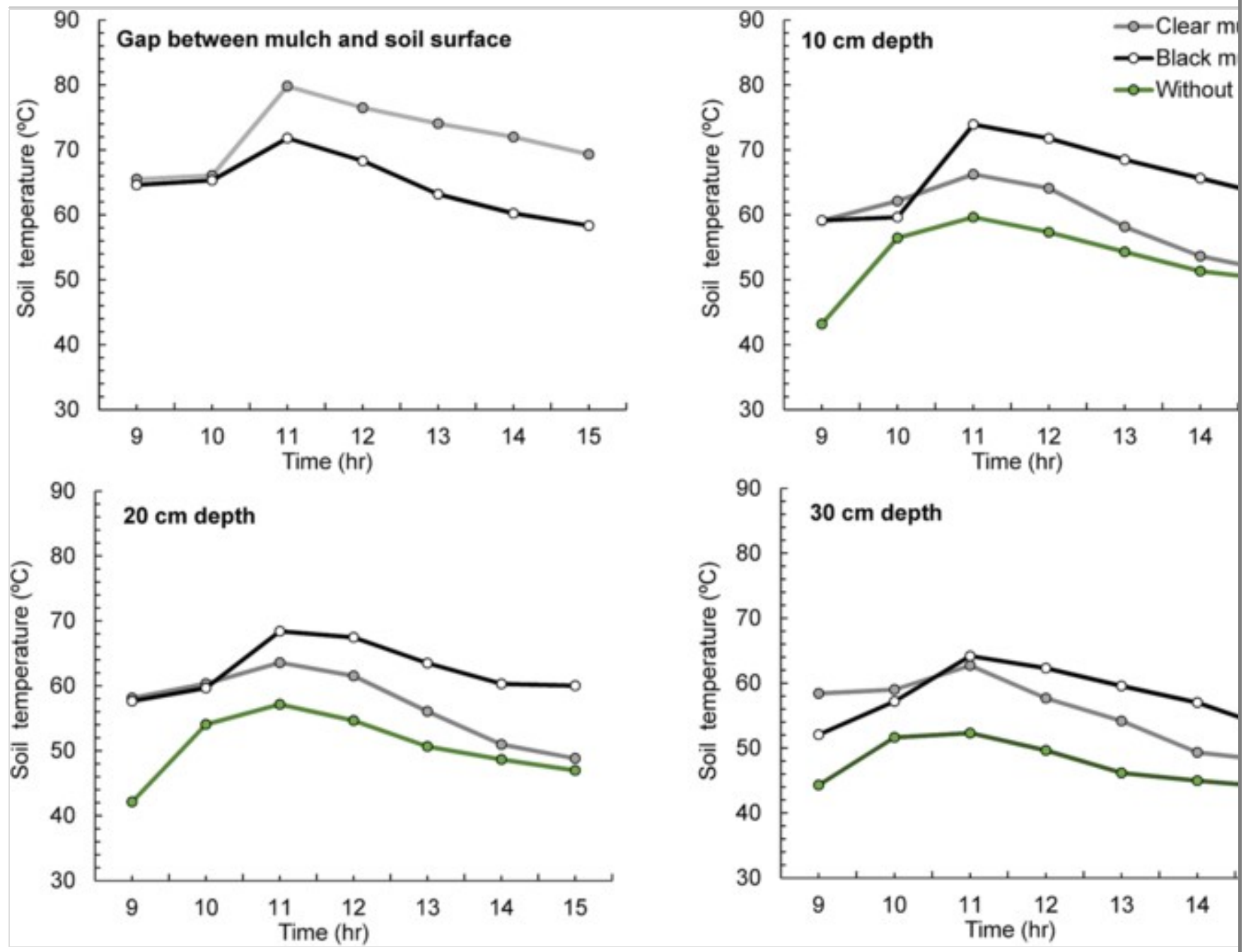
Table 2

Application of Tukey test to check statistically significant differences in diurnal soil temperature changes

\begin{tabular}{|l|l|l|l|l|}
\hline & Comparisons & $\begin{array}{c}\text { Black vs } \\
\text { clear }\end{array}$ & $\begin{array}{r}\text { Black vs } \\
\text { control }\end{array}$ & $\begin{array}{r}\text { Clear vs } \\
\text { control }\end{array}$ \\
\hline & Gaps & $P=0.017$ & - & - \\
\hline $\begin{array}{l}\text { Soil depth } \\
\text { (cm) }\end{array}$ & $0-10$ & $P=0.046$ & $P=0.001$ & $P=0.061$ \\
\hline & $10-20$ & $P=0.061$ & $P=0.257$ & $P=0.328$ \\
\hline & $20-30$ & $P=0.406$ & $P=<0.001$ & $P=0.006$ \\
\hline
\end{tabular}

At $0-10 \mathrm{~cm}$, statistically significant differences at the $5 \%$ level were found between the use of black and both the clear plastic mulch $(P=0.046)$ and the control $(P=0.001)$. However, this was not the case between the clear and the control treatment $(P=0.061)$. It is observed that the black and clear plastics reached average diurnal temperatures above $59^{\circ} \mathrm{C}$, and for the control plot, this was above $43{ }^{\circ} \mathrm{C}$. During all times, the black plastic plots registered higher soil temperatures than both the clear one and the control treatments, reaching maximum average values from 65 to $74^{\circ} \mathrm{C}$ between 11:00 and 14:00 $\mathrm{h}$. The highest soil temperatures reached by the clear plastic was $66^{\circ} \mathrm{C}$ at $11: 00 \mathrm{~h}$. At the end of the monitoring time $(15: 00 \mathrm{~h})$, the clear plastic and the control plots showed similar temperatures $\left(50-51^{\circ} \mathrm{C}\right)$. Conversely, the black plastic displayed average soil temperatures higher than $62{ }^{\circ} \mathrm{C}$.

For the middle soil layer $(10-20 \mathrm{~cm})$, the black and clear plastics did not show statistically significant differences $(P=0.061)$ at the 5\% level. Between the hours of 9:00 and 10:00 h, soil temperature was similar for the clear and black mulches with average values between 57.7 and $60{ }^{\circ} \mathrm{C}$. For all treatments, the soil temperature peaked at 11:00 $\mathrm{h}$, the black plastic registering a maximum average value of $68^{\circ} \mathrm{C}$. After the peak, the clear plastic clearly demonstrated a faster rate of decline followed by the control treatment. At the end of the monitoring period, the clear plastic showed similar temperatures to the control plot, an average of $48.8{ }^{\circ} \mathrm{C}$. The average soil temperature for the monitoring hours was $60{ }^{\circ} \mathrm{C}$ for the black plastic, $48.8{ }^{\circ} \mathrm{C}$ for the clear plastic, and $47{ }^{\circ} \mathrm{C}$ for the control treatment.

Finally, at 20-30 cm, no significant statistical differences between the black and 
clear plastics were obtained $(P=0.406)$. On the other hand, both soil management systems showed significant differences when compared with the control treatment. It is important to remark that the average of the clear plastic soil temperature is similar at the $0-10$ and $10-20 \mathrm{~cm}$ depths, but higher than at 20-30 cm. These results confirmed that, when using the clear plastic, the soil temperature becomes lower than the black one, but it can conserve temperature along the soil profile depth. However, the black plastic showed a decrease by $5{ }^{\circ} \mathrm{C}$ from the surface to the deepest layer, although the hourly temperature was always higher than for the clear plastic and the control plots.

\section{Variation of soil thermal characteristics with soil depths and management systems}

Figure 3 depicts box plots of the effect of the soil management system and depth on the soil thermal characteristics (thermal flux 㐏 it is qh please format

$h$ thermal conductivity $k$, and the volumetric heat capacity $C_{\mathrm{v}}$ ). It is observed that 吾 it is $q h$ please format

$h$ decreases with increasing soil depth for all treatments (Fig. 3a-c). The average 吾 it is $q h$ please format

$h$ at $10 \mathrm{~cm}$ soil depth with the clear mulch was $55 \mathrm{~W} \mathrm{~m}^{-2}$, which was much

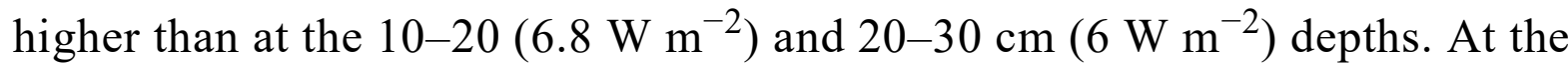
$10 \mathrm{~cm}$ soil depth, the black mulch recorded a higher average 顽 it is $q h$ please format

$h\left(63 \mathrm{~W} \mathrm{~m}^{-2}\right)$ than the clear mulch. Also, a lower average value of 㐏 it is $q h$ please format

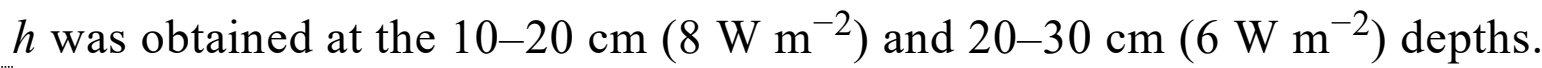
For the clear and black mulch plots, the values were drastically different at the $0-10 \mathrm{~cm}$ soil depth. However, the differences decreased significantly for the two deeper soil layers.

\section{Fig. 3}

Variation of thermal soil characteristics (thermal flux, soil thermal conductivity, and soil volumetric heat capacity) with soil management system and soil depth AQ4 

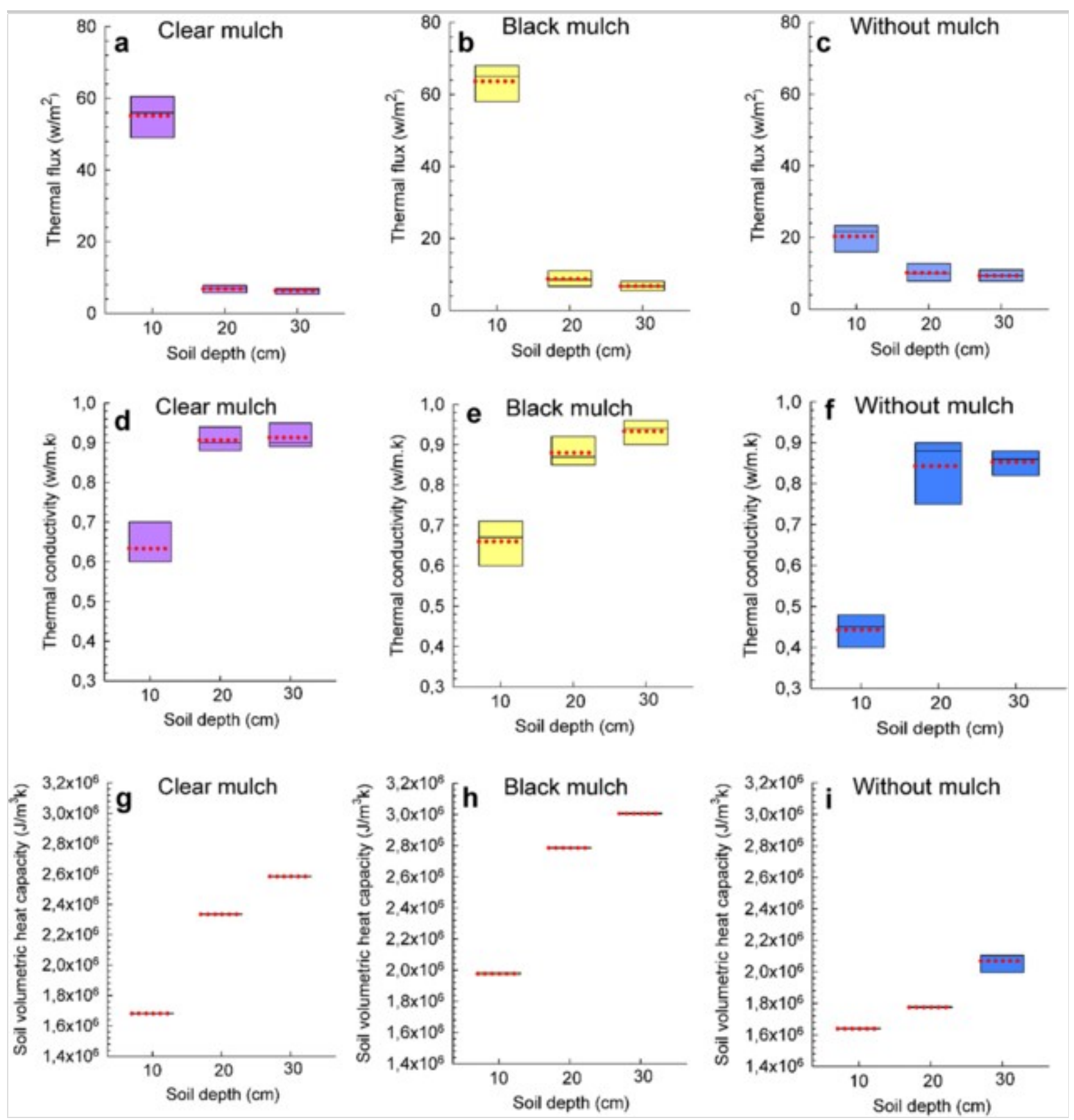

The results indicated that the soil management systems also influenced soil thermal conductivity at different soil depths (Fig. 3d-f). Both the clear and black plastics recorded mean values of $k$ around $0.9 \mathrm{~W} \mathrm{~m}^{-1} \mathrm{~K}^{-1}$ at the two deeper depths, while the surface layer recorded around $0.65 \mathrm{~W} \mathrm{~m}^{-1} \mathrm{~K}^{-1}$. For the control plot, the variability of the results was higher than for the soils with plastic mulches, although all the values were in general lower than the mulch plots.

In general, $C_{\mathrm{v}}$ increased with soil depth for all the soil management systems (Fig. $3 \mathrm{~g}-\mathrm{i}$ ). The highest mean value of $C_{\mathrm{v}}$ was $25 \times 10^{5} \mathrm{~J} \mathrm{~m}^{-3} \mathrm{~K}^{-1}$ for the soils 
with clear mulch and $3 \times 10^{6} \mathrm{~J} \mathrm{~m}^{-3} \mathrm{~K}^{-1}$ for the black mulch at the $20-30 \mathrm{~cm}$ depth. For 10-20 and 0-10 cm soil depths, the clear mulch registered $2.3 \times 10^{6}$ and $1.6 \times 10^{6} \mathrm{~J} \mathrm{~m}^{-3} \mathrm{~K}^{-1}$, respectively, while the values for the black mulch were slightly higher at $2.7 \times 10^{6}$ and $1.9 \times 10^{6} \mathrm{~J} \mathrm{~m}^{-3} \mathrm{~K}^{-1}$, respectively.

Table 3 shows an analysis of the variance (ANOVA) for the individual effect of the soil management systems and soil depths on soil thermal characteristics and their interaction. These results are presented according to the coefficient of determination, mean square error, least significant difference, and standard errors of differences of means. Significant differences $(P<0.05)$ were observed in the plastics used per soil depth for all the soil thermal characteristics. Soil 荦 $h, k$, and $C_{\mathrm{v}}$ showed a significant positive correlation with both clear and black plastic mulches used as well as with soil depths.

\section{Table 3}

Results of analysis of variance (ANOVA) for the interaction of the mulching systems and soi
$R^{2}$
M.S Error

\begin{tabular}{|c|c|c|c|c|c|c|c|c|}
\hline Treatment & Df & $\begin{array}{l}\text { Soil } q h \\
\left(W / m^{2}\right)\end{array}$ & $\begin{array}{c}\text { Soil } k \\
(\mathbf{W} / \mathbf{m} \text { K) }\end{array}$ & $\begin{array}{c}\text { Soil } C_{v} \\
\left(J / m^{3} k\right)\end{array}$ & $\begin{array}{l}\text { Soil } q h \\
\left(W / \mathbf{m}^{2}\right)\end{array}$ & $\begin{array}{c}\text { Soil } k \\
(\mathbf{W} / \mathbf{m} \text { K) }\end{array}$ & $\begin{array}{c}\text { Soil } C_{\mathbf{v}} \\
\left(\mathrm{J} / \mathbf{m}^{3} \mathbf{k}\right)\end{array}$ & $\begin{array}{l}\text { Soil } \\
(W / \mathbf{r}\end{array}$ \\
\hline Mulching & 2 & - & - & - & 10.166 & 0.002 & $4.645 \mathrm{E} 8$ & 3.15 \\
\hline Soil depth & 2 & - & - & - & 10.166 & 0.002 & $4.645 \mathrm{E} 8$ & 3.151 \\
\hline $\begin{array}{l}\text { Mulching } \\
\text { vs soil } \\
\text { depth }\end{array}$ & 4 & 0.985 & 0.944 & 0.998 & 10.166 & 0.002 & $4.645 \mathrm{E} 8$ & $5.46 !$ \\
\hline
\end{tabular}

$D f$, degrees of freedom; $R^{2}$, coefficient of determination; $M . S_{\text {Error }}$, mean square error; $L$. of the differences of means; $q h$, thermal flux; $k$, thermal conductivity; $C_{\mathrm{v}}$, volumetric hea

\section{Discussion}

After investigating changes in soil thermal characteristics (TCs) under different soil solarisation systems (black and clear plastics and control) at 3 different soil depths, significant differences among treatments are confirmed. This analysis will clearly help enterprises and farmers in choosing the most efficient plastic mulch. The heat transfer along the soil depth is a complex process influenced by environmental factors (temperature) and soil management techniques (tillage, 
fertilisers, etc.) (Pramanik et al. 2015; Alrtimi et al. 2016). In this paper, only one type of soil was tested under specific conditions. Therefore, we recommend that studies be undertaken on the different representative soil types close to Baghdad and also that these be monitored for more concrete results. It is confirmed that the TCs are mostly controlled by soil bulk density, moisture content, and soil texture (Łydżba et al. 2016; Al-Shammary et al. 2019), which are also linked to thermal flux, soil thermal conductivity, and soil volumetric heat capacity (Levy and Schmidt 2016; Alrtimi et al. 2016).

It is shown in Table 1 that the soils of the study area are characterised by a heavy texture (silty clay; (USA 1975)) in the soil profile. The soils have high values of bulk density and moisture content (Al-Shammary et al. 2018). We observed that the highest average bulk density values were measured at the deepest layer (20-30 cm depth) and the lowest values at the surface layer (0-10 cm depth). This could be the first clear key factor that is controlling soil temperature. These differences may be attributed to the different agricultural management practices throughout the cropping season using machinery to plough the soil, which is more intense for soils with high contents of clays and silts (Ramos et al. 2000; Wang et al. 2014). Furthermore, deeper soils are generally denser because of the overburden of the upper horizons (Chaudhari et al. 2013). Therefore, our results can be put in a context highlighted only under the special conditions of soil texture and management system. The differences in bulk density also affect the water content of the soil layers (Castillo et al. 2003; He et al. 2017). It was observed that the soil moisture content was also higher at the deepest soil layer, which may be attributed to the low soil $\mu$ (drier soil) of the top layer, compared with the middle and bottom layers, the lower evapotranspiration rates, and the consumption of water by the crops (Francone et al. 2010; Ruiz-Sinoga et al. 2011). Therefore, considering all of these key soil characteristics, the differences among soil horizons could be clearly justified. The size and distribution of the solid soil particles clearly affected the thermal conductivity $(k)$ of the soil, which was also confirmed by other previous studies conducted in Iraq (Al-Temmemi 2015).

Furthermore, considering the differences in bulk density, the porosity will also be different. Soil porosity is considered a key factor in soil temperature changes because how easily gas and liquid fluxes can go through the soil depends on the pore sizes and interconnections. It is well-known that air shows very low values 
of $k$ compared with water and solid material (Buczko et al. 2006). Therefore, a higher air content would reduce the contact between soil particles, thus reducing $k$ (Al-Shammary and Al-Sadoon 2014b). Confirming this situation in our studied soils, it would be important to assess if the current soil management system carried out by heavy machinery that increases soil compaction is affecting the thermal conductivity through the soil profile. One example can be noted in the research carried out in the Croatian vineyards by Bogunovic et al. (2017a). They observed in soils tilled by tractors that soil functions such as soil respiration or $\mathrm{CO}_{2}$ was highly affected after each tractor pass. Therefore, another research line for the future should be related to monitoring soil under a no-tillage management system and its influence on TCs. Several authors have highlighted that tillage highly affects some soil responses such as soil and water losses, soil compaction, soil respiration, carbon sequestration, and liberation and the loss of fertility in some extreme cases due to the deterioration of soil aggregates (Adimassu et al. 2019; Buczko et al. 2006; Cerdà et al. 2009).

\section{AQ5}

Another key factor that shows strong differences among soil treatments at different soil depths is the high soil organic matter of the top layer $(0-10 \mathrm{~cm})$ compared with the 10-20, and 20-30 cm soil depths. Soil nutrient contents demonstrated that the surface layer is very rich and has the potential to be very fertile. The high content of organic matter due to human additions also correlates with a higher water retention capacity (Behera and Shukla 2015; Camilli et al. 2016) as was confirmed with our soil analysis. Therefore, the conservation of high organic matter content could enhance soil heat transmission through the soil profile. On the other hand, it would also be important to investigate whether fertilisers are kept in the soil all year round with the same high rates and that no losses occur after extreme rainfall events or tractor passes as other authors have demonstrated in agricultural fields (Borrelli et al. 2016; Szalai et al. 2016).

Improving TCs is a matter of great concern in soil science, as thermal TCs are of importance for the determination of rates and directions of soil physical, chemical, and biological processes, as well as for energy and mass exchange with the atmosphere (Pramanik et al. 2015). After monitoring of the mean daily soil temperature, significant differences of TCs between black and clear plastics were confirmed. Our findings showed that the use of plastics increases soil temperature, but black mulch treatment was the most effective at reaching the 
highest peak temperatures at the different soil depths. However, we observed smaller variations during the day, and at different soil depths, using the clear plastic. The black mulch was more effective in heating the air and soil beneath it because the heat was trapped by the solarisation system, reducing the soil thermal loss which increases soil temperature (Tesfaye et al. 2016; Ito et al. 2011). Therefore, when farmers intend to use a specific kind of plastic, several factors related to the daily temperature variations, crop thermal necessities, and root development have to be taken into account (Anikwe et al. 2007; Vela et al. 2017; Cohen et al. 2018). The highest soil 顽

it is $q h$ please format

$h$ was also obtained using the black mulch treatments, which can be attributed to their higher efficiency in controlling evaporation from the soil as demonstrated on the growth and yield of tomatoes with the influence of three types of mulch in Ibadan in the south of Nigeria (Awoodoyin et al. 2007).

Soil $k$ with mulch treatments (clear or black) was also higher compared with soils without mulch at the $0-10 \mathrm{~cm}$ soil depths. This is the case because soil $k$ is directly proportional to soil volumetric moisture content. Soil mulching increases soil moisture content by decreasing water loss through evaporation, consequently increasing soil $k$ compared with the control treatment, which corroborates the studies carried out in Iraq and Poland by Al-Shammary and Al-Sadoon (2014b) and Usowicz et al. (2016), respectively. Also, soil $C_{\mathrm{v}}$ increases when mulching is used. Soils with black mulch treatment obtained the highest soil $C_{\mathrm{v}}$ compared with soil with clear mulch or without treatment. Soil $C_{\mathrm{v}}$ increases as soil moisture increases, and, as a consequence, the heat storage capacity of the soil also increases (Alnefaie and Abu-Hamdeh 2013).

The influence of the depth of the soil tillage system was also reported as significant on soil 吾 it is $q h$ please format

$h$ due to the increase in soil temperature near the soil surface by solar radiation (Al-Shammary and Al-Sadoon 2014b). The current study demonstrated that, when soil depth increases, soil 吾 it is $q h$ please format

$h$ decreases (Fig. 3). This can be attributed to soil 吾 it is $q h$ please format $h$ being directly proportional to soil $k$, but tillage decreases soil $k$ values by reducing the bulk density (Abu-Hamdeh 2000; Merante et al. 2017; Ingman et al. 2015), resulting in a decrease in soil 吾 it is $q$ h please format 
$h$. These results also corroborate the findings of other studies reported in Canada and Northern Germany by (Azooz et al. 1997; Dec et al. 2009), respectively.

It is recommended that future research should be directed to the following:

i) To find the relationship between the use of plastic mulch, organic carbon, and soil nutrients during the year;

ii) To examine the possible correlation between the use of plastic mulch on TCs and crop production depending on the type of plant;

iii) To assess the economic costs and farmers' perceptions of the use of plastic mulch and the impacts on soil properties and crop production;

iv) To assess the environmental impact of the use of plastic mulch when an organic farming system is developed without fertiliser and no-tillage practices.

\section{Conclusions}

The use of plastic mulches greatly benefits the TCs at different soil depths. However, we observed several significant differences in soil management systems. The black plastic mulch reached higher diurnal soil temperatures than both the clear mulch and the control treatments. However, the clear plastic mulch showed more regular conservation of the temperature within the soil profile and during the day. Therefore, we underline that, depending on the type of crop and soil physical properties such as bulk density, soil water content, particle size distribution, and organic matter, the effects of the intended type of plastic mulch must be thoroughly checked as mentioned in the above discussions. It is considered necessary to investigate the relationship between the type of plastic mulch, crop production, economic costs, farmers' perceptions, and their possible environmental impacts.

\section{Publisher's note}

Springer Nature remains neutral with regard to jurisdictional claims in published maps and institutional affiliations. 


\section{References}

Abu-Hamdeh, N. H. (2000). Effect of tillage treatments on soil thermal conductivity for some Jordanian clay loam and loam soils. Soil and Tillage Research, 56(3), 145-151. https://doi.org/10.1016/S0167-1987(00)00129-X .

Adimassu, Z., Alemu, G., \& Tamene, L. (2019). Effects of tillage and crop residue management on runoff, soil loss and crop yield in the humid highlands of Ethiopia. Agricultural Systems, 168, 11-18.

Al-Kaisi, M. M., Yin, X., \& Licht, M. A. (2005). Soil carbon and nitrogen changes as influenced by tillage and cropping systems in some Iowa soils. Agriculture, Ecosystems \& Environment, 105(4), 635-647.

Al-Shammary, A., \& Al-Sadoon, J. J. G. (2014a). Influence of tillage depth, soil mulching systems and fertilizers on some thermal properties of silty clay soil. 2, 18-32.

Al-Shammary, A. A. G., \& Al-Sadoon, J. N. A. (2014b). Influence of tillage depth, soil mulching systems and fertilizers on some thermal properties of silty clay soil. European Journal of Agriculture and Forestry Research, 2(2), $1-16$.

Al-Shammary, A. A. G., Al-Sadoon, J. N. A., \& Lahmod, N. R. (2016). Influence of the soil solarization management and fertilizer on soil temperature under different soil tillage systems. Journal of Agricultural Science, 8(2), 98.

Al-Shammary, A. A. G., Kouzani, A., Saeed, T. R., \& Rodrigo-Comino, J. (2019). A new digital electromechanical system for measurement of soil bulk density. Computers and Electronics in Agriculture, 156, 227-242. https://doi.org/10.1016/j.compag.2018.11.015 .

Al-Shammary, A. A. G., Kouzani, A. Z., Kaynak, A., Khoo, S. Y., Norton, M., \& Gates, W. (2018). Soil bulk density estimation methods: a review. Pedosphere, 28(4), 581-596. https://doi.org/10.1016/S1002-0160(18)60034-7 
Al-Temmemi, M. I. A. A., F.M (2015). Flow in porous media (Middle Technical university .). Iraq.

Alliaume, F., Rossing, W., Tittonell, P., Jorge, G., \& Dogliotti, S. (2014). Reduced tillage and cover crops improve water capture and reduce erosion of fine textured soils in raised bed tomato systems. Agriculture, Ecosystems \& Environment, 183, 127-137.

Almahmood, H. (2010). Study of some physical and chemical characterizations of water from southern Iraqi marshlands after Rehabiliation/2003.

Alnefaie, K. A., \& Abu-Hamdeh, N. H. (2013). Specific heat and volumetric heat capacity of some saudian soils as affected by moisture and density. In International Conference on Mechanics, Fluids, Heat, Elasticity and Electromagnetic Fields, (pp. 139-143).

Alrtimi, A., Rouainia, M., \& Haigh, S. (2016). Thermal conductivity of a sandy soil. Applied Thermal Engineering, 106, 551-560.

Alzubaydi, J. H., \& Alamar, H. A. (2016). Evaluation of some geotechnical properties of chosen soils from Al-Massab Al-Aam channel slopes (middle sector) of Iraq. Iraqi Journal of Science, 57(4A), 2444-2456.

Anikwe, M., Mbah, C., Ezeaku, P., \& Onyia, V. (2007). Tillage and plastic mulch effects on soil properties and growth and yield of cocoyam (Colocasia esculenta) on an ultisol in southeastern Nigeria. Soil and Tillage Research, 93(2), 264-272.

Awoodoyin, R., Ogbeide, F., \& Oluwole, O. (2007). Effects of three mulch types on the growth and yield of tomato (Lycopersicon esculentum Mill.) and weed suppression in Ibdan; rainforest-savanna transition zone of Nigeria. Trop. Agric. Res. Ext, 10, 53-60.

Azooz, R. H., Lowery, B., Daniel, T. C., \& Arshad, M. A. (1997). Impact of tillage and residue management on soil heat flux. Agricultural and Forest Meteorology, 84(3), 207-222. https://doi.org/10.1016 
Behera, S. K., \& Shukla, A. K. (2015). Spatial distribution of surface soil acidity, electrical conductivity, soil organic carbon content and exchangeable potassium, calcium and magnesium in some cropped acid soils of India. Land Degradation \& Development, 26(1), 71-79.

Bogunovic, I., Bilandzija, D., Andabaka, Z., Stupic, D., Comino, J. R., Cacic, M., et al. (2017a). Soil compaction under different management practices in a Croatian vineyard. Arabian Journal of Geosciences, 10(15), 340.

Bogunovic, I., Pereira, P., \& Brevik, E. C. (2017b). Spatial distribution of soil chemical properties in an organic farm in Croatia. Science of the Total Environment, 584, 535-545.

Borrelli, P., Paustian, K., Panagos, P., Jones, A., Schütt, B., \& Lugato, E. (2016). Effect of good agricultural and environmental conditions on erosion and soil organic carbon balance: a national case study. Land Use Policy, 50, 408-421.

Brevik, E. C., Steffan, J. J., Rodrigo-Comino, J., Neubert, D., Burgess, L. C., $\&$ Cerdà, A. (2019). Connecting the public with soil to improve human health. European Journal of Soil Science.

Buczko, U., Bens, O., \& Hüttl, R. (2006). Tillage effects on hydraulic properties and macroporosity in silty and sandy soils. Soil Science Society of America Journal, 70(6), 1998-2007.

Camilli, B., Dell'Abate, M. T., Mocali, S., Fabiani, A., \& Dazzi, C. (2016). Evolution of organic carbon pools and microbial diversity in hyperarid anthropogenic soils. Journal of Arid Environments, 124, 318-331.

Castillo, V., Gomez-Plaza, A., \& Martınez-Mena, M. (2003). The role of antecedent soil water content in the runoff response of semiarid catchments: a simulation approach. Journal of Hydrology, 284(1-4), 114-130.

Cerdà, A., Flanagan, D. C., le Bissonnais, Y., \& Boardman, J. (2009). Soil 
erosion and agriculture. Soil \& Tillage Research, 1(106), 107-108.

Chaudhari, P. R., Ahire, D. V., Ahire, V. D., Chkravarty, M., \& Maity, S. (2013). Soil bulk density as related to soil texture, organic matter content and available total nutrients of Coimbatore soil. International Journal of Scientific and Research Publications, 3(2), 1-8.

Cohen, O., Gamliel, A., Katan, J., Kurzbaum, E., Riov, J., \& Bar, P. (2018). Controlling the seed bank of the invasive plant Acacia saligna: comparison of the efficacy of prescribed burning, soil solarization, and their combination. Biological Invasions. https://doi.org/10.1007/s10530-018-1738-8 .

da Silva, D. M. N., Venturim, C. H. P., Valory Capucho, M. E. O., de Oliveira, F. L., \& de Sá Mendonça, E. (2018). Impact of soil cover systems on soil quality and organic production of yacon. Scientia Horticulturae, 235, 407-412. https://doi.org/10.1016/j.scienta.2018.03.024 .

Dec, D., Dörner, J., \& Horn, R. (2009). Effect of soil management on their thermal properties. Journal of Soil Science and Plant Nutrition, 9(1), 26-39.

Dong, J., Steele-Dunne, S. C., Ochsner, T. E., \& van de Giesen, N. (2016). Estimating soil moisture and soil thermal and hydraulic properties by assimilating soil temperatures using a particle batch smoother. Advances in Water Resources, 91, 104-116.

Evett, S. R., Agam, N., Kustas, W. P., Colaizzi, P. D., \& Schwartz, R. C. (2012). Soil profile method for soil thermal diffusivity, conductivity and heat flux: comparison to soil heat flux plates. Advances in Water Resources, 50, 41-54. https://doi.org/10.1016/j.advwatres.2012.04.012 .

Francone, C., Cassardo, C., Spanna, F., Alemanno, L., Bertoni, D., Richiardone, R., et al. (2010). Preliminary results on the evaluation of factors influencing evapotranspiration processes in vineyards. Water, 2(4), 916-937.

Gamliel, A., \& Katan, J. (2005). DISINFESTATION. In D. Hillel (Ed.), Encyclopedia of soils in the environment (pp. 394-400). Oxford: Elsevier. 
Godfray, H. C. J., Beddington, J. R., Crute, I. R., Haddad, L., Lawrence, D., Muir, J. F., et al. (2010). Food security: the challenge of feeding 9 billion people. Science, 327(5967), 812-818.

Griggs, D., Stafford-Smith, M., Gaffney, O., Rockström, J., Öhman, M. C., Shyamsundar, P., et al. (2013). Policy: sustainable development goals for people and planet. Nature, 495(7441), 305-307.

He, B., Wang, H., Huang, L., Liu, J., \& Chen, Z. (2017). A new indicator of ecosystem water use efficiency based on surface soil moisture retrieved from remote sensing. Ecological Indicators, 75, 10-16.

Hu, G., Zhao, L., Wu, X., Li, R., Wu, T., Xie, C., et al. (2016). New Fourierseries-based analytical solution to the conduction-convection equation to calculate soil temperature, determine soil thermal properties, or estimate water flux. International Journal of Heat and Mass Transfer, 95, 815-823.

Ingman, M., Santelmann, M. V., \& Tilt, B. (2015). Agricultural water conservation in China: plastic mulch and traditional irrigation. Ecosystem Health and Sustainability, 1(4), 1-11.

Ito, K., Onishi, T., \& Senge, M. (2011). Soil properties affected by combinations of soil solarization and organic amendment. Paddy and Water Environment, 9(3), 357-366.

Kader, M. A., Senge, M., Mojid, M. A., \& Ito, K. (2017). Recent advances in mulching materials and methods for modifying soil environment. Soil and Tillage Research, 168, 155-166. https://doi.org/10.1016/j.still.2017.01.001 .

Kanaan, H., Frenk, S., Raviv, M., Medina, S., \& Minz, D. (2018). Long and short term effects of solarization on soil microbiome and agricultural production. Applied Soil Ecology, 124, 54-61. https://doi.org/10.1016 /j.apsoil.2017.10.026 .

Kasirajan, S., \& Ngouajio, M. (2012). Polyethylene and biodegradable mulches for agricultural applications: a review. Agronomy for Sustainable Development, 32(2), 501-529. 
Katan, J., \& DeVay, J. E. (1991). Soil solarization: cRC Press.

Katan, J., Greenberger, A., Alon, H., \& Grinstein, A. J. P. (1976). Solar heating by polyethylene mulching for the control of diseases caused by soilborne pathogens. 66(5), 683-688.

Keesstra, S., Mol, G., de Leeuw, J., Okx, J., de Cleen, M., \& Visser, S. (2018). Soil-related sustainable development goals: four concepts to make land degradation neutrality and restoration work. Land, 7(4), 133.

Krishna, K. R. (2016). Push button agriculture robotics, drones, satelliteguided soil and crop management: CRC Press.

Kroetsch, D., \& Wang, C. (2007). Particle size distribution. In Soil sampling and methods of analysis, Second Edition: CRC Press.

Levy, J. S., \& Schmidt, L. M. (2016). Thermal properties of Antarctic soils: wetting controls subsurface thermal state. Antarctic Science, 1-10.

Li, N., Tian, F., \& Hu, H. (2016) Impact of plastic mulch on the surface soil heat flux estimation over cotton in northwest China. In Geoscience and Remote Sensing Symposium (IGARSS), 2016 IEEE International, (pp. 5890-5893): IEEE.

Łydżba, D., Różański, A., Rajczakowska, M., \& Stefaniuk, D. (2016). Random checkerboard based homogenization for estimating effective thermal conductivity of fully saturated soils. Journal of Rock Mechanics and Geotechnical Engineering.

Martínez-Casasnovas, J. A., \& Sánchez-Bosch, I. (2000). Impact assessment of changes in land use/conservation practices on soil erosion in the PenedèsAnoia vineyard region (NE Spain). Soil and Tillage Research, 57(1-2), 101-106.

Mengistu, A. G., van Rensburg, L. D., \& Mavimbela, S. S. W. (2017). The effect of soil water and temperature on thermal properties of two soils developed from aeolian sands in South Africa. CATENA, 158, 184-193. 
https://doi.org/10.1016/j.catena.2017.07.001 .

Merante, P., Dibari, C., Ferrise, R., Sánchez, B., Iglesias, A., Lesschen, J. P., et al. (2017). Adopting soil organic carbon management practices in soils of varying quality: implications and perspectives in Europe. Soil and Tillage Research, 165, 95-106.

Milligan, B., \& O'Keeffe, M. (2018). Global governance of resources and implications for resource efficiency in Europe. Ecological Economics.

Pramanik, P., Bandyopadhyay, K., Bhaduri, D., Bhatacharyya, R., \& Aggarwal, P. (2015). Effect of mulch on soil thermal regimes-a review. International Journal of Agriculture, Environment and Biotechnology, 8(3), 645.

Pullman, G., DeVay, J., Garber, R., \& Weinhold, A. J. S.-B. P. P. (1979). Control of soil-borne fungal pathogens by plastic tarping of soil. 439 .

Ramos, M. C., Nacci, S., \& Pla, I. (2000). Soil sealing and its influence on erosion rates for some soils in the Mediterranean area. Soil Science, 165(5), 398-403.

Ruiz-Sinoga, J., Galeote, M. G., Murillo, J. M., \& Marín, R. G. (2011). Vegetation strategies for soil water consumption along a pluviometric gradient in southern Spain. CATENA, 84(1-2), 12-20.

Shi, C.-h., Hu, J.-r., Wei, Q.-w., Yang, Y.-t., Cheng, J.-x., Han, H.-1., et al. (2018). Control of Bradysia odoriphaga (Diptera: Sciaridae) by soil solarization. Crop Protection, 114, 76-82. https://doi.org/10.1016 /j.cropro.2018.08.020 .

Smith, K. A. (2000). Soil and environmental analysis: physical methods, Revised, and Expanded: CRC Press.

Steinmetz, Z., Wollmann, C., Schaefer, M., Buchmann, C., David, J., Tröger, J., Muñoz, K., Frör, O., \& Schaumann, G. E. (2016). Plastic mulching in agriculture. Trading short-term agronomic benefits for long-term soil 
degradation? Science of the Total Environment, 550, 690-705.

Szalai, Z., Szabo, J., Kovács, J., Mészáros, E., Albert, G., Centeri, C., et al. (2016). Redistribution of soil organic carbon triggered by erosion at field scale under subhumid climate, Hungary. Pedosphere, 26(5), 652-665.

Tesfaye, T., Tigabu, E., Germadu, Y., \& Lemma, H. (2016). Effect of colored polyethylene mulch on soil temperature, growth, fruit quality and yield of tomato (Lycopersicon esculentum Mill.). World Journal of Agriculture Sciences, 12, 161-166.

USA, S. S. S. (1975). Soil taxonomy: a basic system of soil classification for making and interpreting soil surveys: US Government Printing Office.

Usowicz, B., Lipiec, J., Łukowski, M., Marczewski, W., \& Usowicz, J. (2016). The effect of biochar application on thermal properties and albedo of loess soil under grassland and fallow. Soil and Tillage Research, 164, 45-51.

Vela, N., Fenoll, J., Navarro, G., Garrido, I., \& Navarro, S. (2017). Trial of solar heating methods (solarization and biosolarization) to reduce persistence of neonicotinoid and diamide insecticides in a semiarid Mediterranean soil. Science of the Total Environment, 590-591, 325-332. https://doi.org/10.1016 /j.scitotenv.2017.03.013 .

Vogt, D. J., Tilley, J. P., \& Edmonds, R. L. (2015). Soil and plant analysis for forest ecosystem characterization: Walter de Gruyter GmbH \& Co KG.

Walter, K., Don, A., Tiemeyer, B., \& Freibauer, A. (2016). Determining soil bulk density for carbon stock calculations: a systematic method comparison. Soil Science Society of America Journal.

Wang, L., Shi, Z., Wang, J., Fang, N., Wu, G., \& Zhang, H. (2014). Rainfall kinetic energy controlling erosion processes and sediment sorting on steep hillslopes: a case study of clay loam soil from the Loess Plateau, China. Journal of Hydrology, 512, 168-176.

Wilhelm, K., \& Bockheim, J. (2016). Influence of soil properties on active 
layer thermal propagation along the western Antarctic Peninsula. Earth Surface Processes and Landforms, 41(11), 1550-1563.

Zhang, M., Dong, B., Qiao, Y., Yang, H., Wang, Y., \& Liu, M. (2018). Effects of sub-soil plastic film mulch on soil water and salt content and water utilization by winter wheat under different soil salinities. Field Crops Research, 225, 130-140. https://doi.org/10.1016/j.fcr.2018.06.010 .

Zhang, N., \& Wang, Z. (2017). Review of soil thermal conductivity and predictive models. International Journal of Thermal Sciences, 117, 172-183. https://doi.org/10.1016/j.ijthermalsci.2017.03.013 .

Zribi, W., Aragüés, R., Medina, E., Faci, J. J. S., \& Research, T. (2015). Efficiency of inorganic and organic mulching materials for soil evaporation control. $148,40-45$. 